\title{
Digestibility of dry matter and nutrients from three ingredients by the carps, Labeo fimbriatus (Bloch, 1795) and Cyprinus carpio Linnaeus, 1758 with a note on digestive enzyme activity
}

\author{
B. GANGADHAR, H. UMALATHA, H. GANESH, S. SAURABH AND N. SRIDHAR \\ ICAR-Central Institute of Freshwater Aquaculture, Regional Research Centre, Hesaraghatta Lake P. O. \\ Bangalore - 560 089, India \\ e-mail: gbarlaya@yahoo.co.in
}

\begin{abstract}
This study was conducted in indoor, aerated plastic tubs to estimate the digestibility of dry matter and nutrients by the carps, Labeo fimbriatus (Bloch, 1795) and Cyprinus carpio Linnaeus, 1758, from three feed ingredients viz., azolla, soybean meal and silkworm pupa incorporated at levels ranging from $0-40 \%$ in a diet comprising equal amounts of rice bran and groundnut oil cake using crude fibre as the marker. Activity of the major digestive enzymes was also estimated in the gut of fish at the end of the experimental trial. Utilisation of azolla protein was comparable with that of control diet up to $20 \%$ incorporation in both L. fimbriatus and common carp. Major nutrients from soybean were better utilised up to $40 \%$ incorporation by the two species. Protein digestibility from silkworm pupae increased at $20 \%$ incorporation and decreased at $40 \%$ in L. fimbriatus, while fat and nitrogen-free extract digestibility was higher at $20-40 \%$ incorporation. In common carp, higher digestibility of protein and fat was recorded at 10-30\% inclusion levels of silkworm pupa.
\end{abstract}

Keywords: Azolla, Cyprinus carpio, Digestibility, Labeo fimbriatus, Silkworm pupa, Soybean

\section{Introduction}

Digestibility which is the quantification of the digestive processes provides a relative measure of the extent to which ingested food and its nutrient components are digested and absorbed by the animal. Apparent digestibility coefficients (ADCs) vary between fish species and feedstuffs. Determining the digestibility of nutrients in a feedstuff is important not only to enable formulation of diets that maximise the growth of cultured fish by providing appropriate amounts of available nutrients, but also to limit the wastes produced by the fish. Digestibility of individual ingredients in the compounded diet is considered as one of the important factors affecting the growth of fish (De Silva et al., 1990); therefore, digestibility evaluation of each ingredient is desirable before incorporation in the diet.

Azolla has been recognised as one of the potential ingredients for use in aquaculture (Gangadhar et al., 2014; 2015). It is easy to cultivate and has high productivity and nutritive value. Azolla pinnata is a species of aquatic fern found in quiet and slow-moving water bodies round the year (Lumpkin and Puckett, 1982). Use of azolla as a fish feed ingredient is well documented (Dutta, 2011).

Soybean, Glycine sp. is another most promising plant protein ingredient because of its high protein content and excellent amino acid profile, easy availability, reasonable price and lower faecal nutrient output (Castro et al., 2011). Soybean meal is used in the diets of various carp and catfish species. Fish meal substitution in feeds at quantities of up to $50-60 \%$ by soybean meal has been practiced in recent years (Dawood et al., 2015; Priyadarshini et al., 2015).

Silkworm pupae are wastes from the silkworm industry, often discarded in the open environment or used as fertiliser. Due to high protein content, silkworm pupa meal has been found to be a suitable livestock feed, notably for monogastric species like poultry, pigs and fish (Trivedy et al., 2008). Silkworm pupa is more suitable than mustard oil cake and rice bran as a feed ingredient in carps (Chakrabarthy et al., 1973). Studies have shown that it could be included up to $30-50 \%$ in the diets of carps (Jayaram and Shetty, 1980; Nandeesha et al., 2000) and mahseer (Shyama, 1993).

Labeo fimbriatus (Bloch, 1795), commonly called 'fringe-lipped carp' has been considered as a candidate for species diversification in carp polyculture. Though slow-growing, this medium sized carp is in good demand due to high market value, excellent flavour and meat quality (Basavaraju et al., 1995). Cyprinus carpio Linnaeus, 1758, the common carp, accounts for the world's second highest farmed fish production in Asia (Milstein, 1992). 
The present study was conducted to evaluate the digestibility of dry matter and nutrients from three ingredients: azolla, soybean meal and silkworm pupa by the carps, Labeo fimbriatus and Cyprinus carpio. The activity of major digestive enzymes was also estimated in the gut of fish fed varied levels of the test ingredients, to validate the results.

\section{Materials and methods}

Experimental diets

The basal diet comprised groundnut oilcake, rice bran, finger millet (binder) and vitamin-mineral mixture. Four experimental diets were formulated for each ingredient replacing groundnut oilcake and rice bran in the basal diet at 10, 20, 30 and 40\% levels (Umesh et al., 1994) (Table 1). Azolla pinnata plants were harvested from fish culture ponds, sun dried for 2-3 days, packed in polythene bags and powdered before feed preparation. Soybean meal (Soya), silkworm pupae (SWP), groundnut oil cake, rice bran and finger millet were procured locally. Groundnut oilcake, soybean meal, silkworm pupae and finger millet were dried and powdered. All the ingredients were sieved through a fine meshed screen $(0.5 \mathrm{~mm})$. The required quantity of the ingredients was mixed with hot water to make a dough and it was pressed through a hand pelletiser to get uniform sized pellets $(2 \mathrm{~mm})$.

Table 1. Ingredient proportion (\%) and proximate composition $(\%$, mean $\pm \mathrm{SD})$ of experimental feeds

\begin{tabular}{|c|c|c|c|c|c|}
\hline & Control & $\begin{array}{l}10 \% \text { Azolla/ } \\
\text { Soya/SWP* }\end{array}$ & $\begin{array}{l}20 \% \text { Azolla/ } \\
\text { Soya/SWP }\end{array}$ & $\begin{array}{l}30 \% \text { Azolla/ } \\
\text { Soya/SWP }\end{array}$ & $\begin{array}{l}30 \% \text { Azolla/ } \\
\text { Soya/SWP }\end{array}$ \\
\hline \multicolumn{6}{|l|}{ Ingredients } \\
\hline Groundnut oil cake & 45 & 40 & 35 & 30 & 25 \\
\hline Rice bran & 45 & 40 & 35 & 30 & 25 \\
\hline Ragi & 9 & 9 & 9 & 9 & 9 \\
\hline Azolla/Soya/SWP* & 0 & 10 & 20 & 30 & 40 \\
\hline Vitamin \& mineral mix & 1 & 1 & 1 & 1 & 1 \\
\hline \multicolumn{6}{|l|}{ Proximate composition } \\
\hline \multicolumn{6}{|l|}{ Azolla feed } \\
\hline Moisture & $5.79 \pm 0.08$ & $5.60 \pm 0.07$ & $4.87 \pm 0.10$ & $4.53 \pm 0.06$ & $4.60 \pm 0.06$ \\
\hline Crude protein & $26.23 \pm 0.31$ & $25.85 \pm 0.43$ & $25.98 \pm 0.25$ & $24.96 \pm 0.32$ & $24.85 \pm 0.68$ \\
\hline Fat & $7.40 \pm 0.43$ & $7.46 \pm 0.07$ & $7.42 \pm 0.10$ & $8.16 \pm 0.06$ & $7.33 \pm 0.06$ \\
\hline Ash & $6.99 \pm 0.02$ & $8.51 \pm 0.07$ & $10.23 \pm 0.02$ & $12.12 \pm 0.14$ & $13.55 \pm 0.11$ \\
\hline Crude fiber & $7.81 \pm 0.02$ & $7.88 \pm 0.30$ & $6.24 \pm 1.11$ & $6.41 \pm 0.31$ & $6.69 \pm 0.85$ \\
\hline NFE & $45.78 \pm 1.51$ & $44.70 \pm 0.69$ & $45.27 \pm 0.89$ & $43.83 \pm 1.83$ & $42.97 \pm 2.21$ \\
\hline Gross energy $\left(\mathrm{kJ} \mathrm{g}^{-1}\right)$ & 16.68 & 16.43 & 16.54 & 16.35 & 15.86 \\
\hline \multicolumn{6}{|l|}{ Soybean meal feed } \\
\hline Moisture & $5.64 \pm 0.04$ & $5.09 \pm 0.07$ & $5.15 \pm 0.04$ & $5.99 \pm 0.06$ & $5.08 \pm 0.06$ \\
\hline Crude protein & $27.61 \pm 2.16$ & $29.44 \pm 0.03$ & $30.81 \pm 0.02$ & $31.11 \pm 0.05$ & $33.68 \pm 0.04$ \\
\hline Fat & $6.78 \pm 0.34$ & $6.82 \pm 0.05$ & $5.68 \pm 0.36$ & $4.13 \pm 0.30$ & $4.07 \pm 0.87$ \\
\hline Ash & $6.75 \pm 0.04$ & $7.16 \pm 0.02$ & $7.46 \pm 0.02$ & $7.61 \pm 0.07$ & $7.92 \pm 0.02$ \\
\hline Crude fiber & $7.61 \pm 0.17$ & $7.10 \pm 0.04$ & $6.85 \pm 0.08$ & $5.65 \pm 0.16$ & $5.74 \pm 0.13$ \\
\hline NFE & $45.62 \pm 2.08$ & $44.40 \pm 0.12$ & $44.05 \pm 1.42$ & $45.51 \pm 1.04$ & $43.51 \pm 1.77$ \\
\hline Gross energy $\left(\mathrm{kJ} \mathrm{g}^{-1}\right)$ & 16.72 & 16.94 & 16.75 & 16.46 & 16.68 \\
\hline \multicolumn{6}{|l|}{ Silk worm pupa feed } \\
\hline Moisture & $6.67 \pm 0.02$ & $6.42 \pm 0.02$ & $6.22 \pm 0.01$ & $5.95 \pm 0.01$ & $5.53 \pm 0.02$ \\
\hline Crude protein & $26.74 \pm 0.17$ & $29.27 \pm 0.60$ & $32.97 \pm 0.74$ & $34.91 \pm 0.60$ & $35.65 \pm 1.02$ \\
\hline Fat & $6.92 \pm 0.36$ & $9.02 \pm 0.23$ & $10.28 \pm 0.38$ & $12.47 \pm 0.97$ & $15.45 \pm 1.06$ \\
\hline Ash & $6.65 \pm 0.04$ & $6.20 \pm 0.02$ & $5.81 \pm 0.05$ & $5.52 \pm 0.03$ & $5.38 \pm 0.06$ \\
\hline Crude fiber & $6.83 \pm 0.31$ & $8.66 \pm 1.48$ & $6.29 \pm 0.38$ & $6.35 \pm 0.04$ & $6.61 \pm 0.56$ \\
\hline NFE & $46.18 \pm 0.51$ & $40.42 \pm 1.69$ & $38.43 \pm 0.89$ & $34.81 \pm 0.83$ & $31.38 \pm 2.31$ \\
\hline Gross energy $\left(\mathrm{kJ} \mathrm{g}^{-1}\right)$ & 16.68 & 17.08 & 18.06 & 18.73 & 19.46 \\
\hline
\end{tabular}

SWP - Silkworm pupa

*Azolla/Soya/SWP indicate that any one of these three ingredients were used in a given set of feed 


\section{Digestibility trial}

Digestibility of the test ingredients was evaluated in vivo through a short-term trial (Umesh et al., 1994; Nandeesha et al., 1998) conducted in 501 indoor aerated plastic tubs. The experiment was carried out in three phases. In each phase, 5 feeds prepared using one of the three selected ingredients (incorporated at 0, 10, 20, 30 and $40 \%$ levels) were tested on the two test species in triplicates. Ten fingerlings each of L. fimbriatus (6.24-10.02 g) or common carp (7.83-10.51 g) were maintained in each aerated tub and acclimated for a week. Each feed was provided ad libitum to fish in triplicate tanks every morning at $1000 \mathrm{hrs}$. The fish were allowed to feed for $6 \mathrm{~h}$. At the end of the feeding period, the unconsumed pellets were siphoned out. On the following day, faecal matter was collected by filtering the water with a $15 \mu \mathrm{m}$ meshed nylon cloth, dried, pooled and stored for proximate analysis. About 50\% of water from each tub was replaced with freshwater every day after faecal matter collection. Feeding and faecal matter collection was done for a period of 45-60 days depending on the amount of faecal matter collected. Proximate composition of pelleted feed and faecal matter was analysed as per AOAC (1995). Energy content of the feed ingredients and diets was calculated following Mayes (1990). Dry matter and nutrient digestibility were calculated according to Maynard and Loosli (1972). Crude fibre was used as the reference marker (De Silva et al., 1990; Krontveit et al., 2014).

\section{Analyses of digestive enzyme activity}

On termination of the experiment, three fish from each tub were sacrificed for digestive enzyme activity analyses. The gut was dissected out and homogenised in ice cold condition with distilled water and centrifuged at $16,000 \mathrm{rpm}$ for $20 \mathrm{~min}$ at $4^{\circ} \mathrm{C}$. The supernatant was stored at $20^{\circ} \mathrm{C}$ until further use. Total soluble protein of the homogenate was measured using Folin-phenol reagent (Lowry et al., 1951).

Activity of proteases viz., total protease (Kunitz, 1947), trypsin and chymotrypsin (Erlanger et al., 1961) and carboxypeptidases (Appel, 1974) was estimated. Amylase and cellulase were assayed by hydrolysing starch and CM-cellulose respectively, followed by estimation of reducing sugars (Nelson, 1944). Para nitro phenyl acetate was used as the substrate for assessment of lipase activity (Licia et al., 2006).

\section{Statistical analyses}

Data on digestibility and digestive enzyme activity were compared employing one-way ANOVA.
Homogeneity of variances was checked using Levene's test. Further, pair-wise comparison of treatment means was done by Duncan's multiple range test $(p=0.05)$ (Duncan, 1955).

\section{Results}

Digestibility

The total dry matter digestibility (DMD) and major nutrient digestibility values recorded during the trials are given in Table 2. The DMD and protein digestibility decreased $(p<0.05)$ in the two species at 30 and $40 \%$ azolla inclusion levels. However, digestibility of lipid and nitrogen free extract (NFE) did not vary $(\mathrm{p}>0.05)$ among the groups.

In the case of soybean meal, digestibility values for L. fimbriatus increased with incorporation levels and showed highest value $(\mathrm{p}<0.05)$ at $30 \%$, declining thereafter. However, with common carp, the digestibility values were higher $(\mathrm{p}<0.05)$ at $40 \%$ inclusion, with no difference $(p>0.05)$ between the control and other inclusion levels.

Incorporation of silkworm pupa had no effect ( $>0.05$ ) on total DMD in L. fimbriatus. While protein digestibility increased $(p<0.05)$ with $20 \%$ incorporation, it decreased at $40 \%$, compared to the control. Fat and NFE digestibility was higher $(\mathrm{p}<0.05)$ at $20-40 \%$ incorporation. In common carp, higher digestibility of DMD, protein and fat was recorded at 10-30\% inclusion levels of pupa, with a decrease thereafter. The differences in NFE digestibility were insignificant $(\mathrm{p}>0.05)$.

\section{Digestive enzyme activity}

The activity pattern of digestive enzymes in the gut of L. fimbriatus and common carp fed azolla diets is given in Fig. 1. While total protease and amylase activities were higher $(\mathrm{p}<0.05)$ at $10 \%$, trypsin activity was less $(\mathrm{p}<0.05)$ at all incorporation levels and that of chymotrypsin did not vary significantly $(\mathrm{p}<0.05)$. Carboxypeptidases showed comparatively lesser activity $(\mathrm{p}<0.05)$ at 30 and $40 \%$ incorporations, wherein lipase activity was also lower. In common carp, a slight reduction was observed in the activity of total protease and trypsin. Chymotrypsin activity showed no difference ( $p>0.05)$ among the different treatments, but both the carboxypeptidases showed lower values. Activity of amylase was higher at 30 and $40 \%$ inclusion levels, while lipase activity was similar $(\mathrm{p}>0.05)$ among the different treatments.

Fig. 2. depicts the activity pattern of digestive enzymes in the gut of $L$ fimbriatus and common carp receiving soybean meal incorporated diets. While the activity of total protease did not vary $(\mathrm{p}>0.05)$ among the 
Table 2. Digestibility (\%, mean $\pm \mathrm{SD}$ ) of dry matter and nutrients by L. fimbriatus and C. carpio fed experimental feeds

\begin{tabular}{|c|c|c|c|c|}
\hline Feeds & Total DMD & Protein digestibility & Fat digestibility & NFE digestibility \\
\hline \multicolumn{5}{|l|}{ Azolla } \\
\hline \multicolumn{5}{|c|}{ L. fimbriatus } \\
\hline Control & $63.40 \pm 3.12^{\mathrm{b}}$ & $74.55 \pm 4.01^{\mathrm{b}}$ & $87.72 \pm 3.64^{\mathrm{a}}$ & $81.77 \pm 1.01^{\mathrm{a}}$ \\
\hline $10 \%$ & $60.45 \pm 3.15^{\mathrm{b}}$ & $69.24 \pm 3.86^{\mathrm{b}}$ & $87.25 \pm 4.28^{\mathrm{a}}$ & $82.34 \pm 2.01^{\mathrm{ab}}$ \\
\hline $20 \%$ & $60.63 \pm 4.48^{\mathrm{b}}$ & $68.61 \pm 4.36^{\mathrm{b}}$ & $90.15 \pm 2.29^{\mathrm{a}}$ & $85.12 \pm 2.02^{\mathrm{b}}$ \\
\hline $30 \%$ & $53.21 \pm 4.26^{\mathrm{a}}$ & $60.38 \pm 4.32^{\mathrm{a}}$ & $88.41 \pm 1.03^{\mathrm{a}}$ & $83.23 \pm 2.03^{\mathrm{ab}}$ \\
\hline $40 \%$ & $53.68 \pm 3.21^{\mathrm{a}}$ & $59.17 \pm 5.10^{\mathrm{a}}$ & $89.09 \pm 3.15^{\mathrm{a}}$ & $81.47 \pm 1.02^{\mathrm{a}}$ \\
\hline \multicolumn{5}{|c|}{ C. carpio } \\
\hline Control & $60.15 \pm 2.33^{b}$ & $69.56 \pm 4.85^{\mathrm{c}}$ & $81.42 \pm 2.65^{\mathrm{b}}$ & $83.43 \pm 1.03^{\mathrm{a}}$ \\
\hline $10 \%$ & $55.92 \pm 0.89^{\mathrm{b}}$ & $59.45 \pm 3.92^{\mathrm{b}}$ & $77.07 \pm 1.53^{\mathrm{a}}$ & $82.78 \pm 2.02^{\mathrm{a}}$ \\
\hline $20 \%$ & $56.57 \pm 3.63^{b}$ & $58.28 \pm 4.25^{\mathrm{b}}$ & $77.98 \pm 2.58^{\mathrm{ab}}$ & $84.98 \pm 0.99^{\mathrm{a}}$ \\
\hline $30 \%$ & $48.66 \pm 1.52^{\mathrm{a}}$ & $49.21 \pm 2.61^{\mathrm{a}}$ & $80.99 \pm 1.13^{\mathrm{b}}$ & $84.26 \pm 0.98^{\mathrm{a}}$ \\
\hline $40 \%$ & $48.84 \pm 3.86^{\mathrm{a}}$ & $47.63 \pm 4.58^{\mathrm{a}}$ & $80.27 \pm 1.26^{\mathrm{ab}}$ & $83.70 \pm 1.42^{\mathrm{a}}$ \\
\hline \multicolumn{5}{|c|}{ Soya bean } \\
\hline \multicolumn{5}{|c|}{ L. fimbriatus } \\
\hline Control & $60.83 \pm 1.79^{\mathrm{a}}$ & $72.27 \pm 2.78^{\mathrm{a}}$ & $84.31 \pm 2.20^{\mathrm{a}}$ & $77.42 \pm 2.24^{\mathrm{a}}$ \\
\hline $10 \%$ & $64.67 \pm 3.08^{\mathrm{ab}}$ & $74.93 \pm 4.10^{\mathrm{ab}}$ & $87.49 \pm 2.16^{b}$ & $78.91 \pm 0.95^{\mathrm{a}}$ \\
\hline $20 \%$ & $69.23 \pm 4.66^{\mathrm{b}}$ & $82.31 \pm 4.95^{\mathrm{c}}$ & $91.78 \pm 1.42^{\mathrm{c}}$ & $85.04 \pm 1.85^{\mathrm{b}}$ \\
\hline $30 \%$ & $76.78 \pm 0.75^{\mathrm{c}}$ & $83.35 \pm 1.77^{\mathrm{c}}$ & $94.73 \pm 1.16^{\mathrm{c}}$ & $88.26 \pm 0.98^{c}$ \\
\hline $40 \%$ & $69.41 \pm 1.14^{\mathrm{b}}$ & $79.66 \pm 0.34^{\mathrm{bc}}$ & $91.81 \pm 0.45^{\mathrm{c}}$ & $85.13 \pm 0.66^{\mathrm{b}}$ \\
\hline \multicolumn{5}{|c|}{ C. carpio } \\
\hline Control & $64.34 \pm 2.29^{\mathrm{a}}$ & $74.22 \pm 3.60^{\mathrm{a}}$ & $81.56 \pm 2.06^{\mathrm{ab}}$ & $83.11 \pm 2.02^{\mathrm{ab}}$ \\
\hline $10 \%$ & $62.72 \pm 3.42^{\mathrm{a}}$ & $73.76 \pm 2.94^{\mathrm{a}}$ & $79.31 \pm 2.98^{\mathrm{a}}$ & $80.13 \pm 1.49^{\mathrm{a}}$ \\
\hline $20 \%$ & $61.26 \pm 3.78^{\mathrm{a}}$ & $71.84 \pm 4.17^{\mathrm{a}}$ & $80.02 \pm 3.09^{\mathrm{a}}$ & $80.65 \pm 2.24^{\mathrm{a}}$ \\
\hline $30 \%$ & $64.11 \pm 1.78^{\mathrm{a}}$ & $77.21 \pm 1.29^{\mathrm{a}}$ & $83.06 \pm 2.25^{\mathrm{ab}}$ & $80.41 \pm 2.15^{\mathrm{a}}$ \\
\hline $40 \%$ & $69.13 \pm 0.96^{\mathrm{b}}$ & $83.00 \pm 1.74^{\mathrm{b}}$ & $85.54 \pm 1.50^{\mathrm{b}}$ & $85.16 \pm 0.72^{b}$ \\
\hline \multicolumn{5}{|c|}{ Silk worm pupa } \\
\hline \multicolumn{5}{|c|}{ L. fimbriatus } \\
\hline Control & $64.80 \pm 3.54^{\mathrm{a}}$ & $73.38 \pm 1.95^{\mathrm{b}}$ & $85.52 \pm 1.76^{\mathrm{a}}$ & $80.97 \pm 2.11^{\mathrm{a}}$ \\
\hline $10 \%$ & $65.10 \pm 3.65^{\mathrm{a}}$ & $74.73 \pm 2.05^{\mathrm{bc}}$ & $88.59 \pm 1.44^{b}$ & $81.32 \pm 2.90^{\mathrm{a}}$ \\
\hline $20 \%$ & $68.71 \pm 0.38^{\mathrm{a}}$ & $77.64 \pm 0.48^{\mathrm{c}}$ & $92.93 \pm 0.46^{\mathrm{c}}$ & $87.07 \pm 0.14^{b}$ \\
\hline $30 \%$ & $66.59 \pm 3.01^{\mathrm{a}}$ & $75.38 \pm 1.51^{\mathrm{bc}}$ & $94.27 \pm 1.05^{\mathrm{cd}}$ & $87.67 \pm 0.96^{\mathrm{b}}$ \\
\hline $40 \%$ & $65.39 \pm 1.79^{\mathrm{a}}$ & $69.71 \pm 1.19^{\mathrm{a}}$ & $95.28 \pm 0.36^{\mathrm{d}}$ & $88.61 \pm 0.81^{\mathrm{b}}$ \\
\hline \multicolumn{5}{|c|}{ C. carpio } \\
\hline Control & $62.40 \pm 1.58^{\mathrm{ab}}$ & $72.51 \pm 1.15^{\mathrm{a}}$ & $77.38 \pm 1.26^{\mathrm{a}}$ & $84.41 \pm 0.56^{\mathrm{a}}$ \\
\hline $10 \%$ & $62.34 \pm 1.90^{\mathrm{ab}}$ & $75.26 \pm 0.60^{\mathrm{b}}$ & $81.42 \pm 1.35^{\mathrm{b}}$ & $81.93 \pm 3.31^{\mathrm{a}}$ \\
\hline $20 \%$ & $64.51 \pm 0.09^{\mathrm{bc}}$ & $78.67 \pm 1.48^{\mathrm{c}}$ & $83.71 \pm 1.79^{b}$ & $84.95 \pm 1.48^{\mathrm{a}}$ \\
\hline $30 \%$ & $66.89 \pm 1.38^{c}$ & $78.66 \pm 1.66^{\mathrm{c}}$ & $83.25 \pm 2.74^{b}$ & $83.07 \pm 0.60^{\mathrm{a}}$ \\
\hline $40 \%$ & $60.19 \pm 2.00^{\mathrm{a}}$ & $72.49 \pm 1.21^{\mathrm{a}}$ & $75.78 \pm 0.10^{\mathrm{a}}$ & $83.13 \pm 1.21^{\mathrm{a}}$ \\
\hline
\end{tabular}

Different superscripts for values in the same column for a given species fed a given ingredient indicate significant difference $(\mathrm{p}<0.05)$

treatments, that of trypsin was higher $(\mathrm{p}<0.05)$ at $20 \%$ and $30 \%$ incorporation levels. Excepting a reduction $(\mathrm{p}<0.05)$ in chymotrypsin activity at $10 \%$ inclusion, no difference $(p>0.05)$ in the activities of chymotrypsin and carboxypeptidases was recorded as compared with the control. Activity of both amylase and lipase was higher at higher inclusion levels of soybean. In common carp, the activity of proteases and amylase was the highest at $40 \%$ inclusion; lipase activity showed higher values at $20-40 \%$ incorporation levels.

Effect of incorporating silkworm pupa in the diets on the digestive enzyme activity of $L$. fimbriatus and common carp is shown in Fig. 3. Total protease and chymotrypsin activities were higher $(\mathrm{p}<0.05)$ in the former at $10-30 \%$ incorporation levels compared to the control, being the highest at $20 \%$ inclusion and showing a decreasing trend 

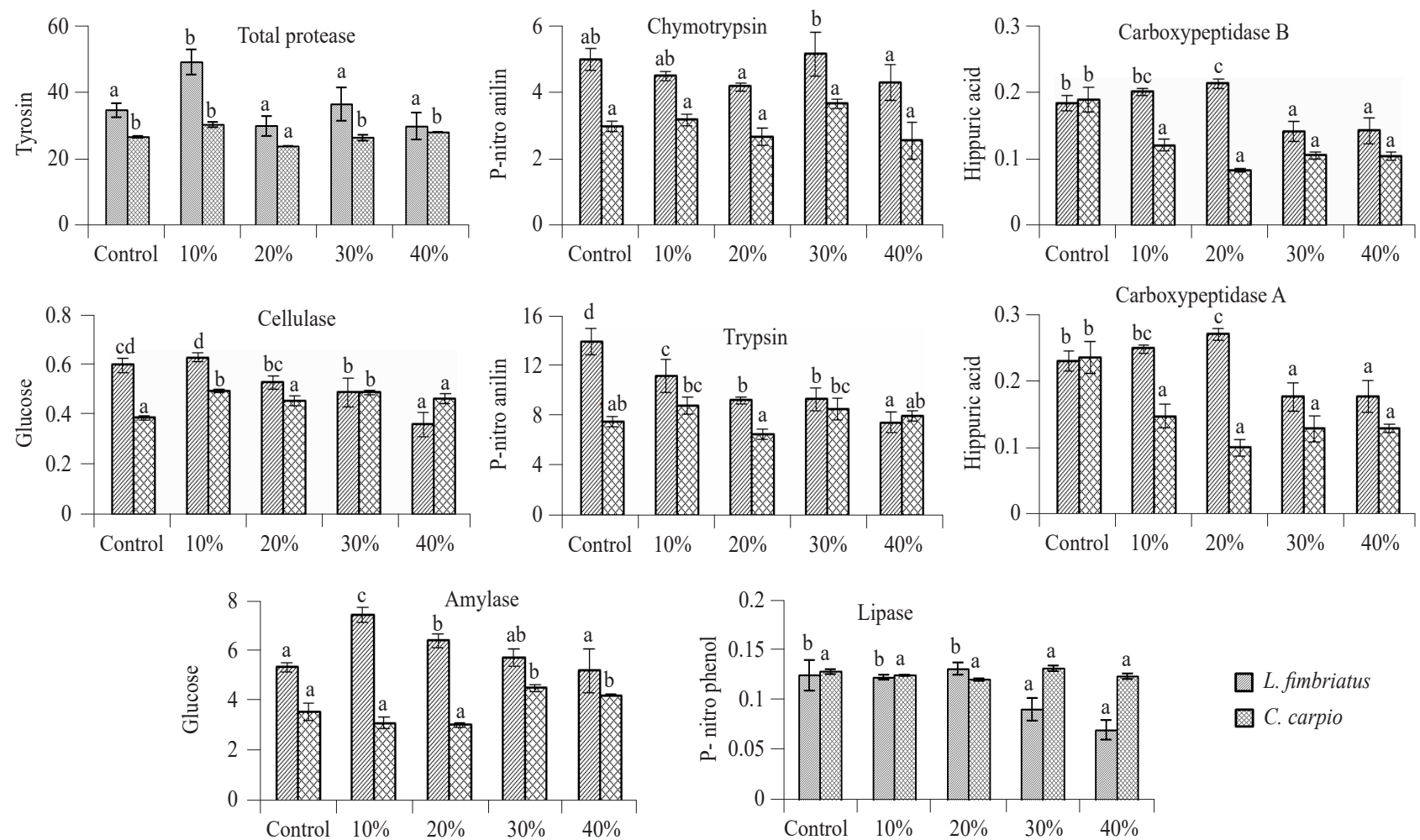

Fig. 1. Activity of digestive enzymes (mean $\pm \mathrm{SD} ; \mu$ moles of product liberated $\mathrm{h}^{-1} \mathrm{mg}$ tissue protein ${ }^{-1}$ at $25^{\circ} \mathrm{C}$ ) in the gut of $L$. fimbriatus and C. carpio fed azolla incorporated diets. Different alphabets on bars in the same graph for a given species indicate statistical difference $(\mathrm{p}<0.05)$
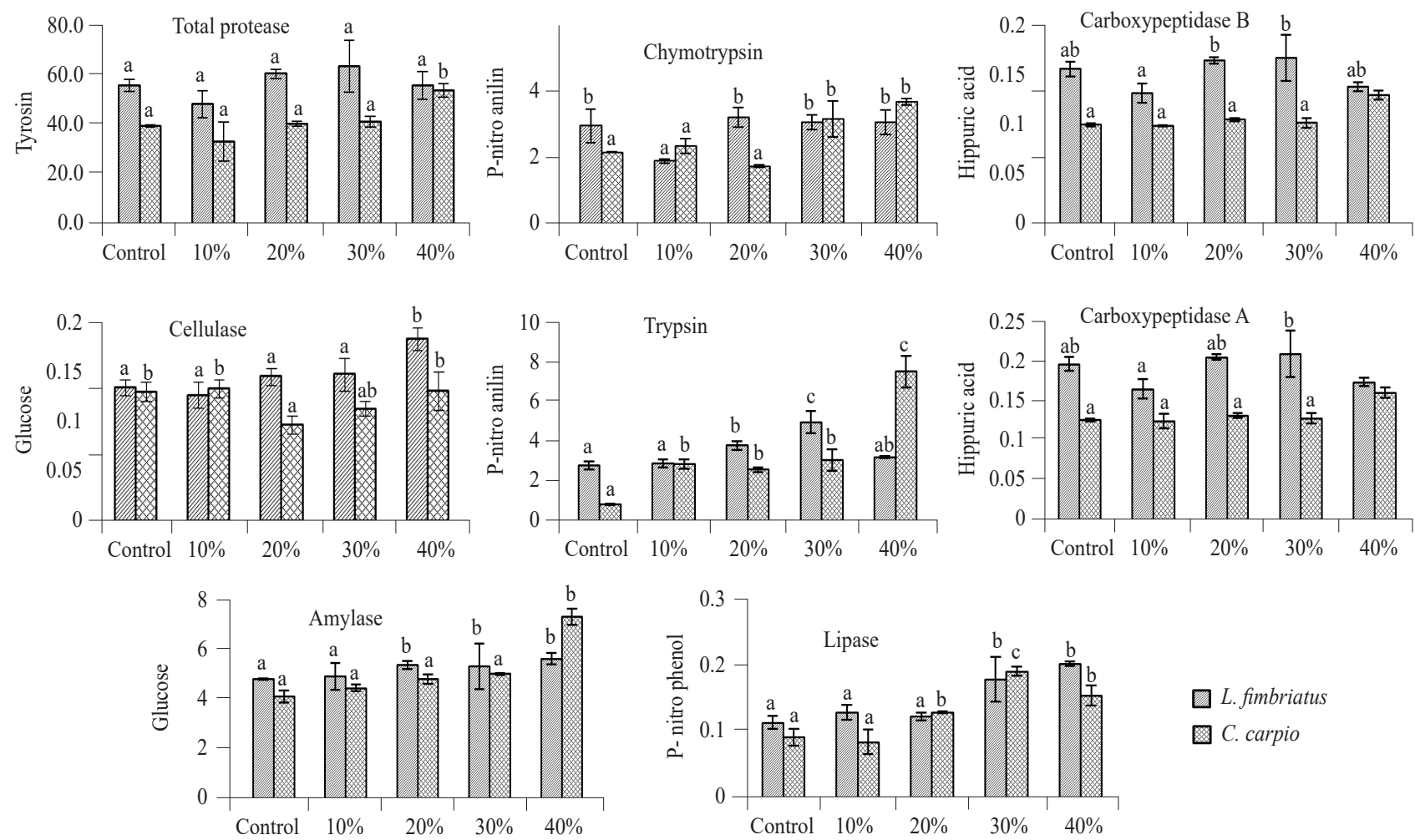

$\square$ L. fimbriatus
. C. carpio

Fig. 2. Activity of digestive enzymes (mean $\pm \mathrm{SD} ; \mu$ moles of product liberated $\mathrm{h}^{-1} \mathrm{mg}$ tissue protein ${ }^{-1}$ at $25^{\circ} \mathrm{C}$ ) in the gut of $L$. fimbriatus and C. carpio fed soybean incorporated diets. Different alphabets on bars in the same graph for a given species indicate statistical difference $(\mathrm{p}<0.05)$ 

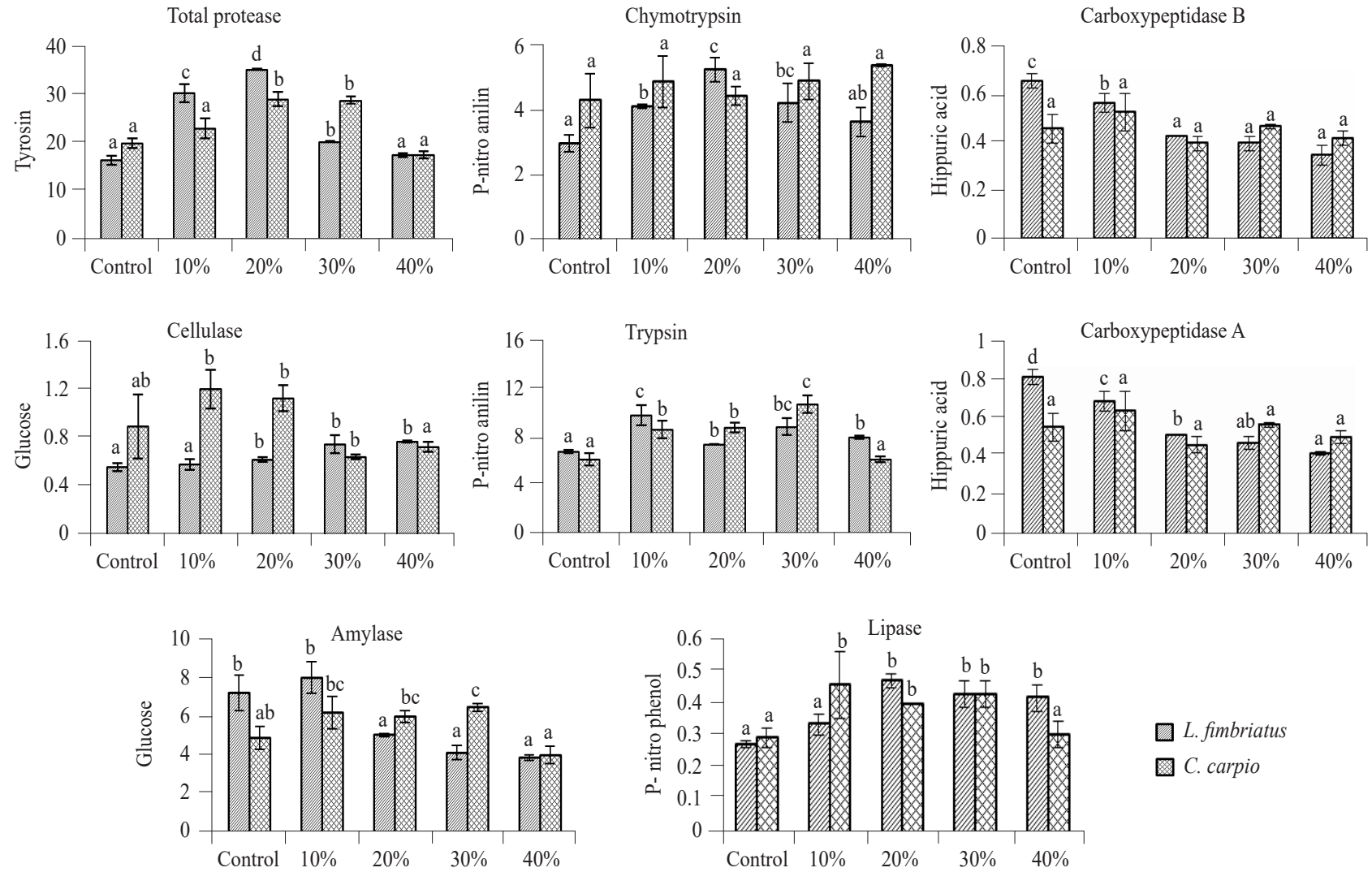

Fig. 3. Activity of digestive enzymes (mean $\pm \mathrm{SD} ; \mu$ moles of product liberated $\mathrm{h}^{-1} \mathrm{mg}$ tissue protein ${ }^{-1}$ at $25^{\circ} \mathrm{C}$ ) in the gut of L. fimbriatus and C. carpio fed silk worm pupa incorporated diets. Different alphabets on bars in the same graph for a given species indicate statistical difference $(\mathrm{p}<0.05)$

at higher levels. The activity of trypsin was higher, while that of other proteases was lower with silkworm pupa incorporation. Further, amylase activity was lower at $20-40 \%$ incorporation levels, whereas lipase activity showed an inverse relationship. In common carp, total protease and trypsin showed higher activities at 10-30\% pupa incorporation, while other proteases showed no difference $(\mathrm{p}>0.05)$. Except at 30\% inclusion, there was no difference in amylase activity among the different groups. Lipase also showed higher activity at 10-30\% incorporation compared to other groups.

\section{Discussion}

The digestibility of different ingredients varies among fish species (Fountoulaki et al., 2005). Digestibility of nutrients and energy from various feedstuffs varies from fish to fish (Refstie et al., 2000). Incorporation of azolla up to $20 \%$ did not have any adverse effect on the DMD and protein digestibility in the two species studied, both decreasing $(\mathrm{p}<0.05)$ at higher inclusion levels. In fry to fingerling rearing trials conducted in manured tanks, the growth of L. fimbriatus was not affected when fed with diets containing $10-40 \%$ azolla, while a decreasing trend was noticed in the performance of mrigal, in terms of growth parameters and feed conversion ratio (FCR), becoming significant at $40 \%$ incorporation (Gangadhar et al., 2014; 2015). In nature, L. fimbriatus feeds mainly on unicellular and filamentous algae and parts of higher aquatic plants (Bhatnagar and Karamchandani, 1970). Azolla protein concentrate could be used up to $16.25 \%$ in the diet of Labeo rohita fry; reduction in growth rate and feed conversion was recorded when fed higher levels (Sheeno and Sahu, 2006). According to Datta (2011), azolla can be incorporated up to $25 \%$ in the diet of L. rohita. Diet containing $15 \%$ azolla performed comparable to the control when fed to $O$. niloticus (Fiogbe et al., 2004). The reduction in growth recorded in rohu fry fed higher levels of azolla protein concentrate was attributed to the imbalance in amino acid make-up of azolla protein. A pinnata protein is limiting in tryptophan and slightly deficient in threonine (Almazan et al., 1986), increasing the demand for the deficient amino acids with increased concentration of azolla in the diet.

The DMD and protein digestibility of azolla incorporated diets was lower in common carp compared to L. fimbriatus. Common carp being an omnivore can eat herbivorous diet of leaves, stalks and seeds of aquatic and terrestrial plants and decayed aquatic plants, but prefers to 
scavenge the pond bottom for insects, crustaceans, crawfish and benthic worms (Dadebo et al., 2015). L. fimbriatus, being a herbivore, is expected to utilise plant ingredients better than common carp. The insignificant difference in the digestibility of lipid and NFE among the treatments in both the species is attributable to the nearly similar levels of lipid and NFE in the test diets and the fact that lipid and carbohydrate in all the diets were of plant origin.

The digestibility of soybean meal incorporated diets varied between the two species tested. In L. fimbriatus, higher digestibility was recorded with all the test diets, whereas in common carp, the values were higher only with $40 \%$ level of incorporation, justifying the species specific differences (Refstie et al., 2000). Heat treatment destroys a large number of anti-nutritional factors present in plant derived ingredients and improves their utilisation by fish (Francis et al., 2001). Since hot water was used during the preparation of feeds in the present study, similar deactivation of anti-nutrients is expected, mitigating adverse effects on digestibility.

Digestibility of the protein fraction of soybean products has been reported to be more than $90 \%$ for common carp (Takeuchi et al., 2002) and $84.06 \%$ for rohu (Hossain et al., 1997). The highest protein digestibility recorded in the present study was around $83 \%$ in both the species at the levels tested. This value is slightly lower than the value $(86.8 \%$ ) for soybean in carp (Kim, 1974), but higher than the values of $69.5 \%$ in jalawat (Law, 1984) and $76.08 \%$ in Anabas testudineus (Ali et al., 2010). The value is, however, similar to the value of $85 \%$ reported for channel catfish (Brown et al., 2002) and 84.67\% for tilapia (Hossain et al., 1992). Similar to our results, Eid and Matty (1989) and Atack et al. (1979) reported protein digestibility values of 83.2 and $83.7 \%$ respectively for soybean meal in common carp. Lipid digestibility was higher at 84.31 to $94.73 \%$ in L. fimbriatus and $79.31-85.54 \%$ in common carp. Values of 81 and $90 \%$ have been reported earlier for channel catfish (Cruz, 1975) and hybrid tilapia (Hanley, 1987). The present results suggest that soybean meal does not affect lipid digestibility in the species tested, except at the highest level of inclusion in L. fimbriatus, this being in accordance with certain earlier studies with other species (Refstie et al., 2000; Venou et al., 2006).

Incorporation of silkworm pupae in the diet up to $40 \%$ had no adverse effect on the digestibility in both the species, except for a reduction in protein digestibility at $40 \%$ in L. fimbriatus. In fact, the value was higher at $20 \%$ incorporation in L. fimbriatus and 20-30\% incorporation in common carp. The highest protein digestibility was $77.64 \%$ in L. fimbriatus, whereas it was $78.67 \%$ in common carp. Hossain et al. (1997) reported a fairly high apparent protein digestibility value of $85.21 \%$ for silkworm pupae which is slightly lower than that reported for silkworm pupae $(91.89 \%)$ in rohu (Jayaram and Shetty, 1980). Kim (1974) however, observed a low value of $63.9 \%$ in common carp. Kitamikado et al. (1964) reported that inclusion of silkworm pupa in the diet of common carp did not significantly affect protein digestibility. Incorporation of pupa in the diets reduced the dietary starch levels due to which an increase in starch digestibility was recorded in L. fimbriatus, as observed in other species (Fountoulaki et al., 2005).

Pupa oil is rich in short chain unsaturated fatty acids, particularly 18:3 (n-3) series which are essential for many of the warm freshwater species (Takeuchi and Watanabe, 1979; Tacon, 1987). In addition, silkworm pupa is known to contain some attractants and growth stimulants (Tsushima and Ina, 1978). Fat digestibility in common carp increased with increasing level of pupa meal (Nandeesha et al., 1990). In the present study also, higher fat digestibility was observed with pupa incorporated diets.

Apparent digestibility coefficient (ADC) of crude protein was higher with animal ingredients as compared to plant ingredients in rohu (Salim et al., 2004). Similar was the finding in the present study when silkworm pupa and azolla were compared. In contrast, when silkworm pupa and soybean were compared, protein digestibility was higher in the latter, indicating the superiority of soybean meal over silkworm pupa for L. fimbriatus and common carp. The digestibility of fat by fish is known to be quite variable and depends on a number of factors, including the source (Appleford and Anderson, 1997). Higher fat digestibility was observed with all the test diets, with the exception of azolla diets in common carp; this was particularly evident in the case of soybean incorporated diets, wherein despite a reduction in dietary fat content (6.78 to $4.07 \%$ ) there was an improvement in fat digestibility, indicating the superiority of soybean meal. The increase in fat digestibility of silkworm pupa diets is attributable to the increase in the dietary fat content due to pupa incorporation. Dietary fat at higher levels $(>10.28 \%)$ had a negative effect on protein digestibility, as reported by Fountoulaki et al. (2005) in gilthead bream.

Carbohydrate digestibility in fish depends on the type, inclusion level and the processing treatments (Chiou and Ogino, 1975; Ufodike and Matty, 1984). Digestibility of NFE in the present study was high and ranged between 77.42 and $88.61 \%$. Herbivorous and omnivorous fish are known to utilise carbohydrate better (Hossain et al., 1992). L. fimbriatus being a herbivore and common carp being an omnivore are expected to better utilise carbohydrate from feed ingredients. Dietary fat level is reported to have a negative effect on starch 
digestibility (Fountoulaki et al., 2005). In the present study, the increased dietary fat levels due to pupa incorporation did not have negative effect on NFE digestibility in both the species tested.

Enzymes play an important role in the digestion and utilisation of feed (Dabrowski and Glogowski, 1977) and dietary nutrients influence digestive enzyme activity (Gangadhara et al., 1997; Fountoulaki et al., 2005). In general, the activity pattern of the digestive enzymes corroborated the digestibility pattern of nutrients in the diets in both the species tested. Soybean meal supplementation at 10 and $20 \%$ levels positively affected $(\mathrm{p}<0.05)$ the activity of total protease, amylase and lipase in catla (Priyadarshini et al., 2011) and common carp (Priyadarshini et al., 2015). In the present study, higher activity of proteases in common carp and trypsin in L. fimbriatus was observed with soybean meal incorporated diets. It has been shown that low levels of trypsin inhibition activity in the diets promote increased production of protein digesting enzymes by the pancreas to counteract the binding of enzymes by trypsin inhibitors (Haard et al., 1996). Nandeesha et al. (2000) recorded higher protease activity in the gut of common carp fed with 40 and 50\% silkworm pupae based diets, while amylase and lipase activities were poor. A reduction in amylase activity with pupa incorporation was also observed in the present study in L. fimbriatus, but not in common carp.

Results of the present study indicate that utilisation of azolla protein is comparable with that of control diet up to $20 \%$ level of incorporation in L. fimbriatus and common carp. Major nutrients from soybean meal are better utilised up to $40 \%$ incorporation. Use of silkworm pupa as a feed ingredient did not adversely affect the digestibility of protein, fat and carbohydrate (NFE) in the species studied.

\section{Acknowledgements}

The authors are grateful the Director, ICAR-Central Institute of Freshwater Aquaculture, Bhubaneswar for the infrastructure facilities provided.

\section{References}

Ali, G., Mehmet, Y., Ayse, K. and Semra, B. 2010. Feeding properties of common carp (Cyprinus carpio L. 1758) living in Hirfanli Dam Lake, Ankara, Turkey. Aquat. Ecol., 18(2): 545-556.

Almazan, G. J., Pullin, R. S. V., Angels, A. F., Manolo, T. A., Agbayani, R. A. and Trono, M. T. B. 1986. Azolla pinnata as dietary component for Nile tilapia, Oreochromis niloticus In: Maclean, J. L., Dizonand, L. B. and Hosillos, L. V. (Eds.), The First Asian Fisheries Forum Proceedings, Asian Fisheries Society, Manila, Philippines, p. 523-528.
AOAC 1995. Official methods of analysis, $16^{\text {th }}$ edn, Association of Official Analytical Chemists, Washington DC, USA.

Appel, W. 1974. Peptidases. In: Bergmeyer, H. U. (Ed.), Methods of enzymatic analysis, vol. 2. Academic Press, New York, p. 949-954.

Appleford, P. and Anderson, T. A. 1997. Apparent digestibility of tuna oil for common carp Cyprinus carpio - effect of inclusion level and adaptation time. Aquaculture, 148: $143-151$

Atack, T. H., Jauncey, K. and Matty, A. J. 1979. Utilisation of some single cell protein by fingerling mirror carp (Cyprinus carpio). Aquaculture, 18: 337-348.

Basavaraju, Y., Devaraj, K. V. and Ayyar, S. P. 1995. Comparative growth of reciprocal carp hybrids between Catla catla and Labeo fimbriatus. Aquaculture, 129: 187-191.

Bhatnagar, G. K. and Karamchandani, S. J. 1970. Food and feeding habits of Labeo fimbriatus (Bloch) in river Narmada near Hoghangabad (M. P.). J. Inland Fish. Soc. India, 2: 30-50.

Brown, M. R. 2002. Nutritional value of microalgae for aquaculture. In: Cruz-Suarez, L. E., Ricque-Marie, D. Tapia-Salazar, M., Gaxiola-Cortes M. G. and Simoes, N. (Eds.), Avancesen NutricionAcuicola VI. Memoriasdel VI Simposium Internacional de NutricionAcuicola.3 al 6 de Septiembre del 2002. Cancun, Quintana Roo, México.

Castro, C. A. C., Hernandez, L. H. H., Araiza, M. A. F., Perez, T. R. and Lopez, O. A. 2011. Effects of diets with soybean meal on the growth, digestibility, phosphorus and nitrogen excretion of juvenile rainbow trout Oncorhynchus mykiss. Hydrobiologia, 21(2): 118-125.

Chakraborty, R. D., Sen, P. R., Chatterjee, D. K. and Kowtal, G. V. 1973. Observations on the relative usefulness of different feed for carp spawn and fry. J. Inland Fish. Soc. India, 5: 182-88.

Chiou, J. Y. and Ogino, C. 1975. Digestibility of starch in carp. Bull. Jap. Soc. Sci. Fish., 41: 465-466.

Cruz, M. E. 1975. Determination of nutrient digestibility in various feedstuffs for channel catfish. Ph. D. Dissertation, Auburn University, USA.

Dabrowski, K. and Glogowski, J. 1977. Studies on the role of exogenous proteolytic enzymes in digestion processes in fish. Hydrobiologia, 54(2): 129-134.

Dadebo, E., Eyayu, A., Sorsa, S. and Tilahun, G. 2015. Food and feeding habits of the common carp (Cyprinus carpio L. 1758) (Pisces: Cyprinidae) in Lake Koka, Ethiopia. Momona. Ethiopian J. Sci. (MEJS), 7(1): 16-31.

Dawood, M. A. O., Koshio, S., Ishikawa, M. and Yokoyama, S. 2015. Effects of partial substitution of fish meal by soybean meal with or without heat-killed Lactobacillus plantarum (LP20) on growth performance, digestibility and immune response of Amberjack, Seriola dumerili juveniles, Biomedical Res. Int., 11 pp. 
De Silva, S. S., Shim, K. F. and Khim Ong, A. 1990. An evaluation of the method used in digestibility estimations of a dietary ingredient and comparisons of external and internal markers and time of faeces collection in digestibility studies in the fish Oreochromis aureus (Steindachner). Reproductive Nut. Dev., 30: 215-226.

Duncan, D. B. 1955. Multiple range and multiple F-tests. Biometrics, 11: 1-42.

Dutta, S. N. 2011. Culture of azolla and its efficacy in diet of Labeo rohita. Aquaculture, 310: 376-379.

Eid, A. E. and Matty, A. J. 1989. A simple in vitro method for measuring protein digestibility. Aquaculture, 79: 111-119.

Erlanger, B. F., Kokowsky, M. and Cohen, W. 1961. The preparation and properties of two new chromogenic substrates for trypsin. Arch. Biochem. Biophys., 95: 271-278.

Fiogbe, E. D., Micha, J. C. and Van Hove, C. 2004. Use of a natural aquatic fern, Azolla microphylla, as a main component in food for the omnivorous phytoplankton ophagous tilapia, Oreochromis niloticus L. J. Appl. Ichthyol., 20: 517-520.

Fountoulaki, E., Alexis, M. N., Nengas, I. and Venou, B. 2005. Effect of diet composition on nutrient digestibility and digestive enzyme levels of gilthead sea bream (Sparus aurata L.). Aquac. Res., 36(13): 1243-1251.

Francis, G., Makkar, H. P. S. and Becker, K. 2001. Anti-nutritional factors present in plant-derived alternate fish feed ingredients and their effects in fish. Aquaculture, 199: 197-227.

Gangadhar, B., Sridhar, N., Saurabh, S., Raghavendra, C. H., Hemaprasanth, K. P., Raghunath, M. R. and Jayasankar, P. 2014. Growth response of Cirrhinus mrigala to azolla (Azolla pinnata) incorporated diets during fry to fingerling rearing. Fishery Technol., 51: 156-161.

Gangadhar, B., Sridhar, N., Saurabh, S., Raghavendra, C. H., Hemaprasanth, K. P., Raghunath, M. R. and Jayasankar, P. 2015. Effect of azolla-incorporated diets on the growth and survival of Labeo fimbriatus during fry to fingerling rearing. Cogent Food and Agriculture, 1: 1055539, doi: 10.1080/23311932.2015.1055539.

Gangadhara, B., Nandeesha, M. C., Varghese, T. J. and Keshavanath, P. 1997. Effect of varying protein and lipid levels on the growth of rohu, Labeo rohita. Asian Fish. Sci., 10: 139-147.

Haard, N. F., Arndt, R. and Dong, F. M. 1996. Estimation of protein digestibility IV. Digestive proteinases form pyloric caeca of coho salmon (Oncorhynchus kisutch) fed soya bean meal. Comp. Biochem. Physiol., 115B(4): 533-540.

Hanley, F. 1987. The digestibility of foodstuffs and the effects of feeding selectivity on digestibility determinations in tilapia, Oreochromis niloticus (L), Aquaculture, 66: $163-179$
Hossain, M. A., Nahar, N., Kamal, M. and Islam, M. N. 1992. Nutrient digestibility coefficients of some plant and animal proteins for tilapia (Oreochromis mossambicus). J. Aquac. Trop., 7(2): 257-265.

Hossain, M. A., Nahar, N. and Kamal, M. 1997. Nutrient digestibility coefficients of some plant and animal proteins for rohu (Labeo rohita). Aquaculture, 151(1): 37-45.

Jayaram, M. G. and Shetty, H. P. C. 1980. Digestibility of two pelleted diets by Cyprinus carpio and Labeo rohita. Mysore J. Agric. Sci., 14: 578-84.

Kim, Y. K. 1974. Determination of true digestibility of dietary protein with $\mathrm{Cr}_{2} \mathrm{O}_{3}$ containing diet. Nippon Suisan Gakkaishi, 40: 651-654.

Kitamikado, M., Monshita, I. and Tachino, S. 1964. Digestibility of dietary protein in rainbow trout. II. Effects of starch and oil contents in diets and size of fish. Bull. Jap. Soc. Sci. Fish., 30: 50-54.

Krontveit, R. I., Bendiksen, E. A. and Aunsmo, A. 2014. Field monitoring of feed digestibility in Atlantic salmon farming using crude fiber as an inert marker. Aquaculture, 426-427: 249-255.

Kuntiz, M. 1947. Crystalline soybean trypsin inhibitor. II. General properties. J. Gen. Physiol., 30: 291-310.

Law, A. T. 1984. Nutritional study of Jelawat, Leptobarbus hoevenii (Bleeker), fed on pelleted feed. Aquaculture, 41: $227-233$

Licia, M. P., Mario, M. R. and Guillermo, R. C. 2006. Catalytic properties of lipase extracts from Aspergillus niger. Food Technol. Biotechnol., 44: 247-252.

Lowry, O. H., Rosebrough, N. J. Farr, A. L. and Randall, R. J. 1951. Protein measurement with the Folin phenol reagent. J. Biolo. Chem., 193: 265-275.

Lumpkin, T. A. and Plucknett, D. L. 1982. Azolla as a green manure: use and management in crop production. Westview Press, Boulder, Colorado, USA. Series No. 15, $230 \mathrm{pp}$.

Mayes, P. A. 1990. Nutrition. In: Murray, R. K., Granner, D. K., Mayes, P. A. and Rodwell, V. W. (Eds.), Harper's Biochemistry, $22^{\text {nd }}$ edn. Prentice Hall International Inc., USA, p. 571-579.

Maynard, L. A. and Loosli, J. K. 1972. Animal nutrition. $6^{\text {th }}$ edn. McGraw-Hill, New York.

Milstein, A. 1992. Ecological aspects of fish species interactions in polyculture ponds. Hydrobiologia, 231: 177-186.

Nadeesha, M. C., Gangadhara, B., Varghese, T. J. and Keshavanath, P. 1998. Effect of feeding Spirulina platensis on the growth, proximate composition and organoleptic quality of common carp, Cyprinus carpio L. Aquac. Res., 29: $305-312$

Nandeesha, M. C., Gangadhara, B., Dathathri, K. Varghese, T. J., Krishnamurthy, D. and Umesh, N. R. 
2000. Growth response and flesh quality of common carp, Cyprinus carpio to higher levels of non-defatted silkworm pupa incorporated diets. Asian Fish. Sci., 13: 235-241.

Nandeesha, M. C., Srikanth, G. K., Keshavanath, P., Varghese, T. J., Basavaraja, N. and Das, S. K. 1990. Effect of non-defatted silkworm pupae in diets on the growth of common carp, Cyprinus carpio. Biological Wastes, 33: $17-23$

Nelson, N. 1944. A photometric adaptation of the Somogyi method for the determination of glucose. J. Biol. Chem., 153: $375-380$.

Priyadarshini, M., Manissery, J. K., Gangadhara B., Rao, L. M. and Keshavanath, P. 2015. Growth performance, body composition and digestive enzyme activity of common carp (Cyprinus carpio) fry fed on soybean and horse gram supplemented diets. Int. J. Aquac., 5(17): 1-7.

Priyadarshini, M., Manissery, J. K., Gangadhara, B. and Keshavanath, P. 2011. Influence of feed, manure and their combination on the growth of Cyprinus carpio (L.) fry and fingerlings. Turkish J. Fish. Aquat. Sci., 11: 577-586.

Refstie, S., Korsoen, O. J., Storebakken, T., Baeverfjord, G., Lein, I. and Roem, A. J. 2000. Differing nutritional responses to dietary soybean meal in rainbow trout (Oncorhynchus mykiss) and Atlantic salmon (Salmo salar). Aquaculture, 190: 49-63.

Salim, M., Aziz, I., Sultan, J. I. and Mustafa, I. 2004. Evaluation of apparent digestibility of fishmeal, sunflower meal and rice polishing for Labeo rohita. Pakistan J. Life Sci., 2: $139-44$.

Sheeno, T. P. and Sahu, N. P. 2006. Use of freshwater aquatic plants as a substitute of fishmeal in the diet of Labeo rohita fry. J. Fish. Aquat. Sci., 1(2): 126-135.

Shyama, S. and Keshavanath, P. 1993. Growth response of Tor khudree to silkworm pupa incorporated diets. In: Kaushik, S. J. and Luquet, P. (Eds.), Fish nutrition in practice, INRA, Paris, p. 779-783.
Tacon, A. G. J. 1987. The nutrition and feeding of farmed fish and shrimp - a training manual. 3. Feeding methods. FAO Field Document, Project GCP/RLA/075/ITA.7/E, Brasilia, Brazil.

Takeuchi, O., Sato, S., Horiuchi, T., Hoshino, K., Takeda, K., Dong, Z., Modlin, R. L. and Akira, S. 2002. Cutting edge: role of Toll-like receptor 1 in mediating immune response to microbial lipoproteins. J. Immunol., 169: 10-14.

Takeuchi, T. and Watanabe, T. 1979. Effect of excess amounts of essential fatty acids on growth of rainbow trout. Bull. Jap. Soc. Sci. Fish., 45: 1517-1519.

Trivedy, K., Kumar, S. N., Mondal, M. and Kumar Bhat, C. A. 2008. Protein banding pattern and major amino acid component in de-oiled pupal powder of silkworm, Bombyx mori Linn. J. Entomol., 5(1): 10-16.

Tsushima, J. and Ina, K. 1978. Survey of feeding stimulants for carp, Cyprinus carpio. J. Agri. Chem. Soc. Japan, 52: $225-229$.

Ufodike, E. B. C. and Matty, A. J. 1984. Nutrient digestibility and growth responses of rainbow trout (Salmo gairdneri) fed different levels of cassava and rice. Hydrobiologia, 119: 83-88.

Umesh, N. R., Dathathri, K., Nandeesha, M. C., Gangadhar, B. and Varghese, T. J. 1994. Digestibility of dry matter and protein and Spirulina platensis by common carp, Cyprinus carpio, with a note on time of faeces collection in digestibility estimations. In: De Silva, S. S. (Ed.), Fish nutrition research in Asia. Proceedings of the Fifth Asian Fish Nutrition Workshop. Asian Fisheries Society Special Publication 9. Manila, Philippines, Asian Fisheries Society, p. $81-84$.

Venou, B., Alexis, M. N., Fountoulaki, E. and Haralabous, J. 2006. Effects of extrusion and inclusion level of soybean meal on diet digestibility, performance and nutrient utilisation of gilthead sea bream (Sparus aurata). Aquaculture, 261: 343-356. 